\title{
Siyasal Bedenin Maliyesi: Piketty, Rousseau ve Neoliberalizm
}

Public Finance of Body Politic: Piketty, Rousseau and Neoliberalism

Yiğit KARAHANOĞULLARI ${ }^{1}$

Duygu TÜRK ${ }^{2}$

Geliş tarihi: 25.07.2018, Kabul tarihi: 26.08.2018, Basım tarihi: 30.09.2018

\section{Özet}

$\mathrm{Bu}$ çalışma, neoliberalizmde ekonomik eşitsizlik sorununu Thomas Piketty'nin tespitlerinden hareketle ele almayı; Piketty'nin hem eşitsizlikte gördüğü sorunda, hem de eşitsizliğe karşı kamu maliyesi aracıllğıyla formüle ettiği önerilerde Rousseau'nun etkisine işaret etmeyi denemektedir. Diğer bir ifadeyle çalışma, eşitlik ile vergi olgusunun ve modern siyasetin temelindeki yurttaşlık, halk egemenliği gibi nosyonlar ile kamu maliyesinin ilişkisine dikkat çekmeyi hedeflemektedir. Bu bağlamda çalışmanın savı, neoliberal dönüşümün eşitsizlik probleminin yanı sıra, modern siyasetin temel kavramlarını yeniden düşünme gereğini doğurduğu yönündedir. Çalışma, bu gereğe dikkat çekmekte ve neoliberalizmin kamusallık aleyhinde işleyişinin, eşitlik lehine demokratik müdahalelerde bulunacak siyasal özne sorununu yarattığını, fakat bu problemin neoliberalizm içinde çözülemeyeceğini vurgulamaya çalışmaktadır.

Anahtar Sözcükler: Piketty, Rousseau, neoliberaližm, eşitsiz̨lik, kamusal ekonomi.

\begin{abstract}
This article attempts to address the problem of economic inequality through Thomas Piketty's historical findings, and tries to point out the impact of Rousseau's idea on Piketty's public finance policy proposals to deal with inequality. In other words, it aims to emphasize to the relationship between equality and tax, besides the relationship between public finance and the notions laying at the heart of modern politics such as citizenship and popular sovereignty. In this sense, neoliberal change gives rise to inequality problems as well as necessitates the rethinking of modern political concepts. Putting emphasize on these requirements, it proposes that the counter-mechanisms of neoliberalism leads to a problem of political subject who is expected to intervene democratically to get equality, and the article concludes with the idea that this problem can not be solved within neoliberalism.
\end{abstract}

Keywords: Piketty, Rousseau, neoliberalism, inequality, public economy.

\footnotetext{
1 Ankara Üniversitesi, SBF, Maliye Bölümü Doç. Dr., https:// orcid.org/0000-0002-1091-8769

yigitkarahanogullari@gmail.com

2 Ankara Üniversitesi, SBF, Siyaset Bilimi ve Kamu Yönetimi Dr., https://orcid.org/0000-0002-2563-5577

duyguturk@gmail.com
} 


\section{Giriş}

Son kırk yıldır politik, ekonomik, yönetimsel alanları dünya genelinde şekillendiren temel 'fenomen'i adlandırmanın en yaygin biçiminin "neoliberalizm" olduğu, buna koşut olarak akademik dünyanın kuramsal ve olgusal düzeyde neoliberalizm üzerine yoğun biçimde düşündüğü, veri ürettiği, tartıştı̆̆1 kolaylıkla tespit edilebilir. Bu eleştirel ve kapsamlı literatürün neoliberalizmi hem kuramsal hem olgusal boyutuyla değerlendirdiği; öte yandan yaşanan dönüşümün dünya genelindeki görünümlerini kavrama çabasıyla şekillendiği düşünülürse, kavramın coğrafi ve toplumsal olarak oldukça farklı deneyimleri içerdiğini söylemek mümkündür. Bu çeşitliliği kapsama girişiminin, neoliberalizm tanımına ve kavramın tutarllığına ilişskin soru işaretlerini de beraberinde getirmesi şaşırtıcı değildir. Bu çalışmada neoliberalizm kavramının kapsamına veya tutarllığına değil, referans verdiği olgunun doğurduğu teorik sorulara, özel olarak da eşitsizlik problemine odaklanmak hedeflenmiştir. Bu amaçla, Thomas Piketty'nin, hem sunduğu veriler hem önerdiği mali politikalarla son dönemde en çok tartş̧lan metinlerden biri olan Yirmi Birinci Yüsynlda Kapital başlıklı çalışması elverişli bir hareket noktası olarak düşünülmüştür.

Piketty'nin sözü edilen çalş̧ması, dünya genelinde yaşanan dönüşümü neoliberalizm adlandırmasına başvurmaksızın değerlendirir ve temel problemi "eşitsizlik" olarak işaret eder; önerilen çözüm, kamu maliyesinin araçlarına başvurmak, vergilendirme yoluyla eşitsizliği azaltıcı ve önleyici politikalar uygulamaktır. Bu çalışma, bu tür bir müdahalenin modern siyasetin başat -kimine göre kurucu- ismi olan Jean Jacques Rousseau'yu güncelleme eğilimi olarak yorumlanabileceği fikrini öne sürmektedir. Yönetimi 'kamusal ekonomi' olarak tanımlayan Rousseau, 'ortak iyi'nin belirleyiciliğini de ekonominin temel ilkesi addetmiş ve bu ilkeyi hayata geçirecek aracı, kamu maliyesi olarak işaret etmiştir. Ne var ki Rousseau'nun önerisi bu siyasal iradenin doğuşunu mümkün kılacak kimi koşulları da kapsar; oysa neoliberalizm ile yaşanan toplumsal dönüşümün bizzat bu iradenin oluşumunu olanaksızlaştıran etkisi de dikkate alınmalıdır. Diğer bir ifadeyle, eşitsizlik problemi salt kamu maliyesinin çözebileceği bir sorun olmanın ötesinde ve bunu önceleyecek biçimde, modern siyasetin eşitlik kabulü üzerine inşa edilmiş yurttaşlık, cumhuriyet, halk egemenliği gibi temel nosyonlarının geçerliliğini tartışmalı hale getirmektedir. Eşitliği bir politik iddia olarak modern siyasal düşüncenin merkezine yerleştiren ve halk egemenliği olarak cumhuriyeti formüle eden Jean Jacques Rousseau'yu güncel kılan bir diğer nedenin de bu olduğu söylenebilir.

$\mathrm{Bu}$ çerçevede, okuduğunuz çalışma öncelikle neoliberal döneme ilişkin Piketty'nin tespitlerini ve politika önerilerini ele alacaktır. Takip eden bölümde, Piketty'nin de ilham aldığını düşündüğümüz Rousseau'nun siyasal bir beden olarak kurguladığ1 toplumda, kamusal ekonominin konumuna ve 
rolüne ilişkin çizdiği çerçeve açıklanacaktır; siyasal terminolojimizi hala belirleyen kavramların Rousseau'nun kuramında hangi araçlarla somutlandığı, siyasal bedenin temel ilkesi olarak eşitliğin sürekliliğini sağlamada mali araçlara başvurunun nasıl formüle edildiği bu bölümün konusu olacaktır. Ardından, ilgili literatürden faydalanarak neoliberal dönüşümün siyasal anlamda yarattığı sonuçlar gözden geçirilecektir. Çalışma, Piketty ve Rousseau'dan edindiğimiz fikirle, neoliberalizmin doğurduğu siyasal özne problemine dikkati çekerek sonlanacaktır.

\section{Piketty ve Verginin Politik Önemi}

İçinde yaşadığımız dönemin temel karakterini adlandırmak amacıyla özellikle eleştirel literatür tarafindan başvurulan neoliberalizm kavramı, 1970'li y1llardan bu yana dünya genelinde yaşanan dönüşümün kuramsal ve olgusal karşılığı olarak kullanılmaktadır. Dolayısıyla bu genel adlandırmanın, kuramsal kabuller ile pratik işleyiş arasındaki açıyı, dünya genelinde coğrafi farkları ve kurumsal gelişmişlik düzeylerindeki eşitsizliği kapsama gibi zor bir işlev üstlendiğini kabul etmek gerekir. Salt olgusal düzeyde dönüşüm deneyimlerine odaklanıldığında dahi, bu deneyimin iktisadi ve yönetsel politikalar kadar, ideolojik, kültürel boyutlarının da hesaba katılması gerektiği açıktır. Bu çeşitlilik, sosyal bilimlerde kimi başka kavramlarda da rastlandığı üzere, bir süre sonra kavramın açıklayıcılığına ilişkin şüpheleri beraberinde getirmiştir. Neoliberalizmin, serbest piyasayla ilintili her girişimi eleştirme niyetiyle başvurulan 'şişirilmiş' bir tabire dönüştüğünü ileri sürerek kavramı kuramsal argümanlarla sınırlamayı savunan yaklaşımlardan söz edilebilir olsa da, ${ }^{3}$ genel eğilimin aksi yönde, yani neoliberalizmi bir politika kümesinin ortak adı olarak kullanma yönünde şekillendiği tespit edilebilir. Diğer bir ifadeyle, teorik argümanlar ile pratik işleyiş arasındaki açıya da dikkati

\footnotetext{
3 Örneğin Thorsten ve Lie'a göre (2009:153), literatürde neoliberalizmin tanımı belirsizdir ve kavram "arzu edilmeyen iktisadi ve politik gelişmeleri tanımlayan genel bir protesto kelimesi"ne dönüşmüştür. Neoliberalizmin 'şişirilmiş' bir tabire dönüştüğünü savunan Mitchell Dean ise (2014:150-151) kavramı, "muarızı Keynesçilik ve refah devleti politikaları olan düşünsel bir hareket"e karşılık gelecek biçimde sınırlandırmayı önerir. Oysa Saad-Filho ve Johnston'a göre (2007:14-15), neoliberalizmi salt kuramsal bir yaklaşım olarak görmek olanaklı değildir çünkü neoliberalizm, "geniş bir toplumsal, iktisadi ve siyasi olgular yelpazesinin üzerinde yükselmektedir" ve bir üretim tarzından beklenebilecek ölçüde "değişmez özellikler kümesi"ne sahip değildir. Dahası, neoliberalizmin teorik-tarihsel kökeninde de Adam Smith, neoklasik iktisat, Avusturya Okulu, monetarizm gibi farklı tarihsel dönemlerde ortaya çıkmış düşünsel akım ve teorik önermeleri biraraya getiren bir çeşitlilik söz konusudur. Benzer biçimde Jeremy Gilbert de $(2013: 7,9)$ neoliberalizmin teorik dayanaklarına bakıldığında kafa karıştırıcı bir çifte-karakterin varlığını tespit etmektedir; buna göre Alman ordoliberalizm çizgisi ile Anglo-Amerikan liberteryanizmi neoliberal düşüncenin iki ayağına denk düşmektedir. Gilbert, pratikte liberteryanizmin katı devlet müdahalesi karşıtlığının retorikte kaldığını, neoliberal uygulamaların her örnekte siyasal iktidarın belirleyici müdahaleleri ile hayata geçtiğini de vurgulamaktadır.
} 
çekerek, eleştirel literatür, neoliberalizmi "siyasal bir proje" olarak görme eğilimindedir. ${ }^{4}$

$\mathrm{Bu}$ "siyasal proje" tespitinin iki temel vurgusunun olduğunu söylemek mümkündür. Öncelikle bu vurgu, neoliberal politikaların uygulamaya konulmasında sıklikla öne sürülen "başka bir alternatifin olmadı̆̆ı" yönündeki sav1 hedefine oturtmakta ve neoliberalizmin 'ekonomik yasalar' vurgusunun barındırdığı 'zorunluluk' kabulünü tartışmaya açmaktadır. İkinci olarak, bu 'zorunlu tedbirlerin' yarattığ1 sonuçları da hesap ederek, neoliberal politikaların eşitsizliği derinleştiren, nüfusun çok sınırlı bir kesiminin lehine işleyen içeriğine dikkati çekmektedir. Buna göre neoliberalizm, özelleştirme, artan oranlı vergi tarifelerinin düşürülmesi, emek piyasasının esnekleştirilmesi, emek örgütlenmelerinin engellenmesi, rekabetçiliğin ve güvencesiz istihdamın kamusal ve özel sektörde aktif biçimde desteklenmesi (Gilbert, 2013:12-15) gibi politik araçlara başvurmuş, "daraltıcı maliye ve para politikalarıla sosyal haklan tırpanlamış", sermaye birikimi sorunlarına "finans dostu" bir çözüm sunmuştur (Saad-Filho ve Johnston, 2007:17-21). Öte yandan, neoliberal programın "milyarlarca insanı yoksulluğa mahkum ederken, tüm dünya nüfusunun yüzde birinin lehine" işlediği tespitleri (Dean, 2008:67), bu siyasal projenin dünya genelindeki 'başarısının' nasıl açıklanabileceği sorusunu ve neoliberalizmin ideolojik boyutunun da hesap edilmesi uyarılarını beraberinde getirmektedir. Buna göre, bireylerin piyasa mekanizması karşısında kendilerini daha kırılgan kılan koşulları ve güvencesizliği bir yaşam biçimi olarak 'normal' ve kaçınılmaz olarak algılayıp içselleştirmelerinde (Gilbert, 2013:15), "başka bir alternatifin olmadığı" sloganının dönemin 'sağduyusu' haline gelmesi etkilidir (Dean, 2008:51). Sözü edilen alternatifsizliğin kabul edilişinde neoliberal politikaların yarattığ1 yapısal dönüşümün, yaratılan yeni koşulların etkisi göz ardı edilmemelidir. Bir diğer ifadeyle, neoliberal politikaların somut, olgusal, istatistiki bilgisi, neoliberal ideolojinin 'başarısı'nı anlamakta hayati önemdedir. Tüm bu

\footnotetext{
4 Örneğin David Harvey (2005:2,19), neoliberal teorinin savlarının, uygulamaya konulan politik projeyi meşrulaştırma işlevi gördügünü ileri sürer. Buna göre, neoliberal teori, bireysel yetenek ve girişim özgürlüğünün, ancak özel mülkiyet hakları, serbest piyasa ve serbest ticareti garanti altına alacak bir kurumsal çerçeve içerisinde gelişebileceğini savunur; ekonomi politik pratiklerin bu varsayıma göre şekillenmesi gerektiğini öne sürer ve devletin işlevini de sözü edilen kurumsal çerçeveyi garantilemek olarak kabul eder. Ne var ki olgusal düzeyde gerçekleşen neoliberalleşme "sermaye birikiminin koşullarını yeniden kuran ve ekonomik elitlerin güçlerini restore eden politik bir proje" olarak deneyimlenmiştir. Ronaldo Munck'a göre de (2007:114) teorik olarak neoliberalizm "ders kitapları dışında" hiç var olmamıştır. Öte yandan Simon Clarke için (2007:105), pratikteki işleyişten hareketle teorik dayanakların gerçekçi olmadığı yönündeki eleştiriler gereksizdir; çünkü tam da teori ve pratik arasındaki bu açı, neoliberalizmin siyasal bir proje olduğunu gösterir. Benzer bir vurguya Ian Bruff ta (2014:114) da rastlamak mümkündür; buna göre, neoliberalizmi 'serbest piyasa' ile tanımlama eğilimi, bizzat neoliberal ideolojinin retoriğini yeniden üretmek anlamina gelmektedir, zira gerçekte işleyiş, kurumları piyasa modeline göre şekillendirme yönündedir.
} 
literatür zenginliği içerisinde, Piketty'nin, neoliberal dönemin eşitsizlik uçurumunu ne ölçüde derinleştirdiğine ilişkin somut verilerle desteklediği tespitlerini ve karşısında bir o kadar somut politika önerilerini dikkate değer k1lan da budur. ${ }^{5}$

Piketty'nin gerek sosyal bilim literatüründe gerekse güncel medyada küresel ölçekte popülerlik kazanan çalışması, kavramsal olarak neoliberalizm ile ilgilenmez; uzun erimli tarihsel verileri kullanarak 1980 sonrası dönemi kapitalizm içi bir birikim ve bölüşüm modeli olarak değerlendirir. Bu dönemin temel özelliği, bölüşüm desenindeki kötüleşme ve servet dağılımındaki radikal eşitsizliktir. Dolayısıyla Piketty'nin çalışması, bu adlandırmaya başvurmasa da neoliberalizmin yarattı̆̆ dönüşümün sonuçlarını çarpıcı verilerle göz önüne sermesi bakımından önemlidir. Piketty ortaya çıkan tabloyu eşitsizlik sorununu merkeze alarak değerlendirir ve odağında mali politikaların bulunduğu alternatif bir politik hattın gerekliliğine işaret eder.

Piketty'nin sunduğu verilerin ortaya koyduğu çarpıcı gerçek, günümüz dünyasının gelir ve servet dağılımı bakımından yüzyıl önceki dünyadan daha eşitsiz bir yapıya sahip olduğudur. Dünya nüfusu içinde en zengin 20 milyonda birlik kesim (7,6 milyarlık bir dünya için sadece 380 kişi), 1987'de dünya toplam servetinin \%0,3'üne el koyarken, 2012 yllında bu oran üç kat artarak \%0,9'a yükselmiştir (Piketty, 2014:469). ${ }^{6}$ ABD'de toplumun en zengin onda birlik kesimi 1910-20 döneminde milli gelirin \%40'1nı alıyorken, bu oran 2000 sonrasında \%50'ye sıçramıș durumdadır (Piketty, 2014:311). Üstelik servet dağılımındaki adaletsizlik gelir dağılımındaki

\footnotetext{
5 Thomas Piketty'nin burada referans verdiğimiz Yirmi Birinci Yǚsylla Kapital başlıklı çalışması, başta Fransa, İngiltere ve ABD olmak üzere, belli başlı kapitalist ekonomiler için ulusal vergi arşivlerinden hareket edilerek üretilen gelir ve servet dağılımı istatistiklerini kullanmakta ve 18 'inci yüzyıldan günümüze uzanan son derece kapsamlı bir dönem için literatürde benzeri olmayan bir iktisat tarihi incelemesi sunmaktadır. Yazar, eserin özünü oluşturan ve bir grup akademisyen ile birlikte hazırladıkları bu veritabanını kendi internet sitesi üzerinden erişilebilir kılmakta ve kamuoyuyla paylaşmaktadır. Bkz. http://piketty.pse.ens.fr/en/capital21c2

${ }^{6}$ Servet dağılımına ilişkin önemli bir başka çalışma olan ve Credit Suisse Research Institute (CSRI) tarafindan hazırlanan Küresel Servet Raporu (Global Wealth Report) da benzer bir tabloyu bulgulamaktadır. 2017 verilerine göre küresel servet eșit bir şekilde dağılmıș olsaydı her bir haneye 56.540 dolarlık servet payı düşüyor olacakken, ortanca servet düzeyi (yani toplumun $\% 50$ 'sinde yer alan hane servet payı) sadece 3.582 dolar olarak hesaplanmıştır. Diğger bir ifadeyle, eşitlik düzeyi yaklaşık 56.500 dolar iken dünya nüfusunun yarısının ulaşabildiği servet 3.500 doların altında kalmaktadır (CSRI 2017; Economist, 16/11/2017). Küresel Servet Raporu'ndan hareketle yapılan hesaplamalara göre 2008 sonrasında küresel ölçekte ortanca servet ile ortalama servet arasındaki oran her yıl düşmektedir; yani servet dağılımı son on yılda giderek kötüleşmiştir. 2017'de ortanca servet 2008 ile hemen hemen aynı düzeyde iken 2008'de 44.651 dolar olan ortalama servet 2017'de 56.541 dolara yükselmiştir; dolayısıla ortalama ile ortanca arasındaki fark açılmış ve eşitsizlik artmıştır.
} 
adaletsizlikten daha derindir: Ücretlilerin en üst $\% 1$ 'lik dilimi toplam ücretlerin \%6-7'sini almakta iken servet dağllımında en üst \%1'lik dilim, toplam servetin \%20'sini almaktadır (Piketty, 2014:442). Bu eğilimler ülkeler arasında farklılaşmakla birlikte, ${ }^{7}$ merkez kapitalist ülkeler, son yüzyllın gelir ve servet dağılımında U biçimli bir desene sahip olmakta ortaklaşmaktadırlar.

Öte yandan II. Dünya Savaşı sonrasında eşitsizlikler azalmakta ve 1980 sonrasında hızla tekrar artış eğilimi sergilemektedir. Piketty'nin sunduğu verilere ilişkin bir diğer çarpıcı olgu da bu dönemlendirmeden çıkan sonuçtur: Gelir ve servet dağılımındaki eşitsizlik, "ekonominin normal işleyişs koşullarında" artma eğilimindedir. Piketty, ekonominin kendi dinamiğinin bu eşitsizliği pekiştirici yönde olduğunu ve bu yönelimin tarihsel olarak yalnızca büyük krizler ve dünya savaşlarıla (dolayısıyla artan vergilerle) tersine çevrilebildiğini tespit etmektedir (Piketty, 2014:293). Tespitin gerisinde sermayenin (vergi öncesi) getiri oranının ekonominin büyüme oranından sistematik olarak daha büyük olması ( $r>g$ ) yatar; “.... bu mantıksal bir gereklilikten ziyade tarihsel bir gerçekliktir” (Piketty, 2014:379). Piketty bu ikisi arasındaki fark1, Iraksama kuvveti olarak adlandırır (Piketty, 2014:27); fark açıldıkça toplumlarda servetin önemi artmakta, ekonomik adalet bozulmaktadır. Büyüme (g), pastanın büyümesi anlamına gelirken, sermaye getiri oranı (r) bu pastadan servet sahiplerinin alacağı payı belirlemektedir. Iraksama güçlendikçe, en üst kesim, sadece servet sahibi olduğu için, zenginliğini arttırabilmektedir. Sermayenin getiri oranı, insanlık tarihinin büyük bir bölümünde üretimdeki büyümenin en az on ile yirmi katı kadardır (Piketty, 2014:380). Yine tarihsel olarak görülmektedir ki, bu tabloda en önemli düzeltici faktör vergilerdir: Vergi sonrası sermayenin getirisi, ekonomik büyüme oranının altına düştügünde, gelir/servet dağılımında düzelme etkisi ortaya çıkmaktadır. Piketty'nin ilkçağdan günümüze büyüme ve sermaye getiri oranların aktardığ tablo, vergi sonrası sermayenin getirisinin yalnızca 1913-1950 döneminde büyüme oranının altına inebildiğini göstermektedir (Piketty, 2014:383). Takip eden yllarda vergi politikaları esnetilmiş, yüksek büyüme oranları sayesinde iki oran nispeten birbirine yakınsamıştır. 1980 sonrası ise vergi politikalarının servetten yana

\footnotetext{
7 Tüm ülkeler arasında en kötü performansı sergileyen ülke kapitalizmin merkezinde yer alan ABD'dir; tarihsel olarak bakıldığında eșitsizliğin iki yüzyıl öncesinden daha derin olduğu görülmektedir: 1810 'da ABD'de en üst yüzde 10'luk kesim toplam servetin \%55-60'1na sahipken, 2010'da bu oran \%70'e ulaşmışırı (Piketty, 2014:374). Eşitsizlik tablosu, farklı büyüme ve piyasa geleneklerini temsil eden Fransa, İsveç, Almanya, Japonya için ve gelişmekte olan ülkeler için bir nebze farklılaşmaktadır. Bu grupta en üst dilimin aldığ1 pay yüzyıl öncesine göre yarı yarıya azalmış olmakla birlikte, 1980 sonrasında tüm ülkeler için eşitsizlikte artış eğilimi söz konusudur (Piketty, 2014:339). İngiltere, Kanada, Avustralya gibi Anglosakson ülkeler de ABD'ye yakın bir performans sergilemekte ve gelir eşitsizliği U biçimli bir eğri olarak ortaya çıkmaktadır; II. Dünya Savaşı sonrasındaki düzelme, 1980 sonrasında hızla tersine dönmektedir (Piketty, 2014: 338).
} 
belirlenmesi ve düşük büyüme olgusu, sermaye getirisi ile büyüme farkının tekrar açılmasıyla sonuçlanmıştır. ${ }^{8} 1980$ sonrası ortaya çıkan bu tablonun değişmemesi durumunda, $r>g$ eşitsizliğinin giderek artması ve 21. yüzyılda eşitsizliğin güçlü bir şekilde derinleşeceği tahmin edilebilmektedir (Piketty, 2014:384). Öte yandan, eşitsizliğin derinleşerek dip noktasına varması yalnızca toplumsal uyumu bozarak demokrasiyi sürdürülemez hale getirmemekte, aynı zamanda -tıpk1 1929 ve 2008 yıllarında olduğu gibifinansal sistemi kırllganlaştırıp büyük krizleri tetiklemektedir.

Politik olarak müdahale edilmediği sürece ekonomik dinamiğin eşitsizliği giderek şiddetlendirdiği tespitinden Piketty'nin vardığ1 sonuç, verginin teknik değil, "açıça politik ve felsefi bir mesele" olduğudur (Piketty, 2014:534). Somut önerileri de bu noktaya odaklanmaktadır: Eşitsizliği azaltıcı güçlü vergi politikaları 21. yüzyilda, kriz veya savaş aracıllğıyla değil, barışçıl ve demokratik bir zeminde hayata geçirilmelidir.

Piketty'nin önerisi üç tür vergide somutlanır: Gelir, veraset ve küresel ölçekte tasarlanacak olan bir servet vergisi. Sonuncusu, yani sermayenin küresel ölçekte vergilendirilmesi, öneriler arasında en dikkat çekici olandır. Piketty'e göre bu ütopiktir, ancak bu, bir referans noktası ve alternatif çözüm önerilerinin değerlendirilmesini sağlayacak bir ölçüt sunması bakımından faydalı bir ütopyadır: Banka hesaplarına dair bilgilerin küresel ölçekte otomatik paylaşımı sağlanmalı, (finansal ve finansal olmayan varlıklar dahil) tüm aktif kalemler sisteme dahil edilmeli, bunlardan borçlar düşülmeli ve oluşacak matrahtan yıllık olarak artan oranlı bir vergi alınmalıdır. Burada amaç, “(...) bir yandan eşitsizlikteki sonsuz artışı ve servetteki sınır tanımayan rraksama kuvvetini durdurmak, diğer yandan finansal piyasalar ve bankacillk sektöründeki krizleri önleyecek bir düzenleme getirmektir"; \%0,1 gibi düşük bir oranda uygulanacak bu vergi, aynı zamanda "ekonomik faaliyeti hukuki bir çerçeveye oturtmak" anlamına da gelecektir (Piketty, 2014:560-565).

Piketty'nin bir diğer önerisi, en üst vergi diliminde radikal bir arttırımdır; burada amaç, "ekonomik açıdan faydasız (hatta zararlı) davranışları makul biçimde sinırlandırırken, büyümenin nimetlerinin daha yaygin bir biçimde dağıtılmasına da izin ver[mektir]" (Piketty, 2014:555-556):

Bir gelir ya da miras dilimine \%70-80 oranında vergi uygulandığında, birincil amaç elbette kamu gelirlerini arttırmak değildir (nitekim bu dilimden asla yüksek bir hasılat sağlanmaz). Amaç daha ziyade yasa koyucunun

\footnotetext{
8 1980'lerle birlikte, en üst gelir vergisi oranları özellikle ABD ve İngiltere için hızla düşmüştür. Bu iki ülkede 1930-1980 arasında \%80-90 arasında seyreden oranlar, 1980-2010 döneminde \%30-40 aralığına düşmektedir. Piketty, bu vergi indirimleriyle, en yüksek gelir diliminin milli gelirden aldığı paydaki artışı tam bir paralellik içinde olduğunu bulgulamaktadır (Piketty, 2014:551).
} 
toplumsal açıdan aşırı ve ekonomik açıdan da atıl olduğuna hükmettiği bu türden gelirlerin ve servetlerin sonunu getirmek ya da aynı düzeyde kalmalarını aşırı maliyetli hale sokup, bu durumu sürdürmek isteyenler üzerinde caydırıcı bir etki yapmaktır. Aynı zamanda bu bir mutlak yasaklama ya da kamulaştırma da değildir. Artan oranlı vergilendirme eşitsizliklerin azaltılması için kullanılan nispeten liberal bir yöntemdir; çünkü bu kurum özel teşvikleri nihayetinde radikal bir şekilde değiştirse de, bunu her zaman hukuk devleti çerçevesinde önceden saptanmış ve demokratik biçimde tartışlmış kurallara uyarak yaparken serbest rekabete ve özel mülkiyete sayg1l davranır. Artan oranlı vergilendirme bu nedenle sosyal adalet ve bireysel özgürlük arasındaki ideal uzlaşmayı temsil eder. Tarih boyunca bireysel özgürlüklere en çok bağlı kalmış ülkeler oldukları söylenebilecek Anglosakson ülkelerin 20. yüzyılda artan oranlı vergilendirme konusunda baş1 çekmeleri bu nedenle tesadüf değildir (Piketty, 2014:547).

Piketty, üst vergi oranının optimal seviyesini \% 80'in üzerinde öngörmekte, bununla birlikte, oranın ancak "ortaklaşa karar alma mekanizması ve demokratik deneyimler" aracilığıla belirlenebileceğini eklemektedir. Kamu maliyesinin vergiler yolu ile politik yeniden inşası olarak görebileceğimiz bu çerçeveyi destekleyen bir diğer boyut ise Piketty'nin yeniden dağglım mekanizmasına dair görüşleridir: Modern devlette yeniden dağglımın temel mekanizması 'hak mantığı'dır. Kamu maliyesinin işleyiş mekanizması açı bir şekilde zenginden alıp fakire dağıtmak yönünde değil, belli sayıda mal ve hizmete erişimde eşitlik prensibi üzerine kurulmuştur (Piketty 2014:516). Piketty, 1776 Bağımsızlık Bildirgesi'ndeki mutluluk peşinde koşma hakkına, 1789 İnsan ve Yurttaş Hakları Bildirgesi'ne ve Rawls'in farklılik prensibine referansla, bu hakların tarihsel sinırlarının yeninden şekillendirilebilir olduğuna işaret eder. Dolayısıyla modern devlette elde edilen emeklilik, eğitim ve sağlık haklarındaki eşitliğe ek olarak, örneğin barınma, kültür ve seyahat haklarını da kapsayacak şekilde genişletilebilir bir kamu maliyesi çerçevesini talep etmek de mümkündür (Piketty, 2014:517). Piketty'nin bu önerilerinin liberal kamu maliyesinin tasarımından bir hayli farklı olduğunu söyleyebiliriz; çünkü buradaki varsayım, devletin kamusal amaç setinin, toplumdaki en kötü yaşam koşullarını iyileştirmek adına hakların genişlemesi ve eşitlenmesi aracıllı̆̆yla sürekli ve tarihsel olarak yeniden şekillenebildiğidir. Liberal yaklaşımda ise devletin sınırları veridir ve dolayısıyla kamu harcamalarının miktarı da bellidir. Oysa Piketty'nin vurgusu, kamusal harcamaların "haklar" çerçevesinde belirleneceği yönündedir; bu durumda kamu gelirleri de harcamalara göre yeniden şekillenmek durumunda kalacaktır. Dolayısıyla hakların genişlemesi çerçevesinde oluşacak kamu harcama ve gelir politikaları, servet ve gelir eşitliğini sağlayıcı yeniden dağııım mekanizmalarını da gerektirecektir.

Bütün bu mali çerçevenin nihai amacının kamu gelirlerini arttırmak mı, piyasa mekanizmalarını tasfiye etmek mi, yoksa basitçe bir finansal kayıt 
mekanizması geliştirmek mi olduğu Piketty tarafindan zaman zaman tutarsız denilebilecek şekilde yanıtlanır. Her üç vergiye ilişkin önerilerde de ana dinamiğin sermayenin getirisini düşürmek olduğu tespit edilebilir; fakat aynı zamanda yukarıda sıralanan sonuçların da ortaya çıkması beklenir. Kuşkusuz sermayenin getirisinin düşürülmesi bile kendi başına radikal bir politik müdahaledir; ne var ki Piketty görece daha radikal sonuçlardan kaçınırcasına önerilerini kimi rezervlerle açıklar: Amacin, servetin yeniden dağılımı olmadığını ve vergilendirmelerin "özel mülkiyet ve rekabet koşullarından ödün vermeden" mümkün olabileceğini özellikle belirtir.

Tüm bunlarla birlikte Piketty'nin önerileri, neoliberal uygulamalar karşısında radikaldir; ekonomik büyüme, piyasa özgürlüğü gibi neoliberalizmin kurucu ve halihazırda ortodoksiye dönüşen argümanlarının karşısına bölüşümü ve ekonomik adaleti koymakta; eşitsizliği insanlığın geleceğini belirleyecek olan büyük bir sorun olarak tanımlamakta ve eşitsizliğin temel nedenini servet/sermaye olarak işaret etmektedir. Böylece kapitalizmin 'kutsal'ı addedebileceğimiz servet, insanlığın temel problemlerinin nedeni olarak tanımlanmakta ve radikal vergi politikalarının hedefi haline getirilmektedir. Tüm bu varsayım ve önerileri, vergilerin "kapitalizmin kamu yararı adına kontrol altına alınmasını" sağlayacağ (Piketty, 2014:579) vurgusuyla birlikte düşündüğümüzde, Piketty'nin yaklaşımındaki Rousseau etkisi çarpıcı hale gelmektedir.

Nitekim Piketty'nin Rousseau'ya olan 'borcuna' dikkati çeken çalışmalar mevcuttur. Mark Clauson (2014), Piketty'nin eşitsizlikleri Rousseau'nun gözünden yorumladığını tespit eder;' benzer biçimde Chris Bertham (2015) da Piketty'nin eşitsizlikteki artışın demokrasinin aleyhine işlediği tespiti ile modern cumhuriyetçi çizginin paralelliğine dikkati çeker. Piketty ile Rousseau'yu daha doğrudan ilişkilendiren bir çalışma ise Capaldi ve Llyod'a aittir; yazarlar John Locke'çu liberal özgürlük ile Rousseau'cu eşitlik anlayışlarını iki rakip gelenek olarak tespit etmekte ve Piketty'nin "ekonomik eşitlik için politik müdahalenin gerekliliği" yönündeki önerisiyle Rousseau'cu gelenekte konumlandığını işaret etmektedirler (Capaldi ve Lloyd, 2016:208)..$^{10}$

\footnotetext{
${ }^{9}$ Clauson'un da eklediği üzere, Piketty'nin eşitsizlik bağlamında bir diğer referans1, toplumsal ve ekonomik eşitsizliklerin ancak toplumdaki en dezavantajlı bireylere fayda sağladığı sürece adil olacağı biçiminde özetlenebilecek olan "farkllılk ilkesi"ni öne süren John Rawls'dur (bkz. Piketty, 2014:517).

10 Bununla birlikte Capaldi ve Llyod, bu geleneğe eleştirel yaklaşmakta ve ekonomik büyümenin eşitsizlik problemini çözeceğini savunarak kendilerini Locke'çu çizgiye yerleştirmektedirler; bu bağlamda Piketty'e yönelttikleri eleştiri, en temelde Rousseau'nun "genel irade"nin somut, ampirik karşllğının belirsizliğine dairdir (Capaldi ve Llyod, 2016:214). Öte yandan yazarlar, küresel yoksulluğun 1970-2006 yılları arasında \% 27'den \% 5'e düştüğü yönündeki bir veriye dayanarak, piyasa ekonomisinin küresel ölçekte başarılı olduğunu da öne
} 


\section{Rousseau ve Siyasal Bedenin Maliyesi}

Kimi yorumculara göre Jean Jacques Rousseau, eşitlik ile siyaset arasındaki modern bağı kuramının temeline yerleştirdiği için (Badiou, 2007:347) veya siyaseti her tür doğallık referansından kopardığ için (Critchley, 2013:33) "modern siyasetin kurucusu"dur. Neoliberal dünyanın eşitsizliği derinleştiren yapısı ve öte yandan, dönüşümün ekonominin 'doğal' yasalarına referansla meşrulaştırıldığı düşünülürse, Rousseau'yu gündeme getiren atmosferin, aynı zamanda modern siyasetin temel kavram ve iddialarını da yeniden düşünme ihtiyacını yansıttığını söylemek mümkündür. Rousseau'nun "genel irade" ve "halk egemenliği" kavramsallaştırmalarıyla çözmeye çalıştığı problemin de güncelliği dikkate değerdir. Rousseau, siyaseti modern toplumsal insanın "özgürlügünü" mümkün kilacak uzlaşımsal, yani yapay, bir çözüm zemini olarak düşünür; buna göre, özgürlük bireylerin yalnızca kendi iradelerine tabi olmaları koşuluyla mümkündür ve toplumsal bağlamda bu koşul yalnızca, siyasal toplumun üyelerinin "eşitliği" ile sağlanabilir. Kendi tarihsel bağlamında düşünüldügünde Rousseau'nun hedefinde 'ayrıcalıklı' sınıfların geniş halk kitlelerini kendilerine tabi kıldıklanı, eşitsizlikçi toplumsal-siyasal sistemin yattığ1 tespit edilebilir. Nitekim Wood'un altını çizdiği üzere (Wood, 1983:301-315) Rousseau'nun çokça tartışılan "genel irade" kavrayışı, halkı herhangi bir ayrıcalı̆ga sahip olmayan bireylerin bütünü olarak görmenin bir formülasyonudur. Rousseau siyasal sistem tarafindan tanınan ayrıcalıklar yoluyla süreklileştirilen eşitsizliği, daha genel düzeyde, hem zengin-yoksul arasında açlan uçurumla hem de bu uçurumu derinleştiren ana faktör olarak para ekonomisinin belirleyici hale gelmesiyle ilişskilendirir. Bunun karşısında, halk egemenliği olarak cumhuriyetin varlığını, ekonomik eşitsizliklere karşı önlem alma koşuluna bağlamaktadır ki Rousseau'yu kendi tarihsel bağlamının ötesine taşıyarak güncel kılan temel savin da bu olduğu söylenebilir. Bu bağlamda, Ansiklopedi maddesi olarak kaleme aldığı Ekonomi Politik başlıklı metni, Rousseau'nun yalnızca ekonomik-mali politika önerilerini değil, aynı zamanda modern cumhuriyetin dayanağ olan halk egemenliğini hangi varlık koşullarına bağladığını anlamak için de hayati önemde bir metindir.

Ekonomi Politik metni, Rousseau'nun aile ile siyasal toplum arasında, dolayısıyla özel ile kamusal alan arasındaki farka dikkat çekmesiyle açılır; doğal duygular, bağlllıklar ve kişisel çıkar tarafindan şekillendirilen hane yönetimi ile ortak akıl ve ortak çıarın yön vermesi gereken siyasal toplum iki başka alandır. Rousseau böylece, siyaseti hem özel, kişisel veya sınıfsal her

sürmektedirler (2016:212-213). Ne var ki ne Rousseau'nun ne de Piketty'nin esas aldığı düzey 'mutlak eşitsizlik' düzeyidir. Dolayısıyla mutlak yoksulluğun azaldığı kabul edilse bile, toplumsal ve küresel yapıyı belirleyenin yalnızca mutlak eşitsizlik değil, aynı zamanda göreli ekonomik eşitsizlik olduğu hesaba katılmalıdır. 
tür 'tikel' çıkarın yönlendiriciliğinden ayrıştırmakta, ${ }^{11}$ hem de doğal, verili ve zorunlu ilişkilerin dişında yapay ve uzlaşıma dayalı bir alan olarak işaret etmektedir. "Ekonomi" kavramını ise Rousseau, hem kişilerin yönetimini, hem mal ve hizmetlerin idaresini kapsayacak biçimde kullanır; sözcügün antik kökenindeki "ev işlerinin veya hanenin idaresi" anlamından ayrıştırmak için de devletin yönetimi anlamındaki ekonomiyi "kamusal" veya "politik" sıfatlarıyla niteler (Rousseau, 2005: 36,7-8). Dolayısıyla politik ekonomi, Rousseau'nun bütün bir halkı 'kendisi dişında hiçbir iradeye tabi olmayan siyasal bir beden' olarak tasarladığı cumhuriyet tasarımında, olağan ihtiyaçları karşılamanın, işleri idare etmenin ve işleyişi sürdürmenin genel adıdır. Bir başka deyişle, politika siyasal bedenin biraraya gelişi ve iradesini 'yasa' olarak formüle edişi iken, politik ekonomi söz konusu yasaların çizdiği çerçevenin içinde kalmak koşuluyla siyasal bedenin mali ve idari işlerini yürütmeye karş1lık gelir. Bu durumda ekonomi, politik iradenin yönelimine tabidir; politik irade ise Rousseau için daima bir bütün olarak siyasal bedenin, yani halkın, ortak iyisini ifade eder. Rousseau'nun terminolojisinde siyasal bedenin eşit üyeleri 'yurttaş'; yurttaşların bütüncül iradesi 'genel irade' adını alır. Siyasal toplumun kendisine koyduğu kurallar olarak 'yasa'lar, genel iradenin ifadesi veya ürünüdür. Siyasal toplum, kendi iradesi dişında bir kurala tabi olmadığı ölçüde halk, kendi kendisinin 'egemeni' durumundadır. Dolayısıyla 'halk egemenliği' olarak cumhuriyet fikri, eşit yurttaşlik zemininde biraraya gelen bireylerin, 'yalnızca kendi ortak iradelerinin ürünü olan yasalara itaat etmeleri' sayesinde özgür kaldıkları kabulüne dayanır.

Rousseau için egemenlik karşısında, yani 'yasa yapma' edimi karşısında "yönetim" veya "kamusal ekonomi", tanımı gereği ikincildir; türevseldir. Yönetimin/kamusal ekonominin ilk ve en önemli ilkesi de doğrudan bu ilişkiyi anlatır: Yönetim, "genel iradeyi izlediği sürece" meşrudur. ${ }^{12}$ Aksi bir hal, yöneticilerin bütünün çıkarlarını değil kendi çıkarlarını, genelin iyiliğini

\footnotetext{
11 Wood'un (1983:304) dikkati çektiği üzere, aile veya hane idaresi ile siyasal toplumu birbirinden ayrıştırması, Rousseau'nun kendi çağının Fransız mutlakiyetçiliğine yönelttiği bir eleştiri olarak da düşünülmelidir. Buna göre mutlakiyetçi rejimin yapısal niteliği, vergilerin, kamusal görevleri üstlenen ayrıcalık sahibi soylular için temel gelir kaynağı olmasıdır. Yöneticiler için kamusal pozisyonlar, bu anlamda 'özel' alandan farksızdır; 'hane idaresi'nde olduğu gibi kişisel çıkarların yönlendiriciliğine tabi durumdadır. (Rousseau'nun yaşadığı dönemde geçerli olan vergiler için ayrıca bkz. Ağdemir, 2018:8-9,17-18).

12 Dolayısıyla Rousseau, halk egemenliğini bir 'devlet biçimi' olarak formüle eder ve bu düzeyde cumhuriyet ile demokrasi arasında fark gözetmez. Egemen güç, devredilemez ve temsil edilemez biçimde halkın -veya siyasal bütünün- kendisine aittir. Öte yandan, işlerin nasıl idare edileceğini gösteren 'yönetim biçimi', egemen halkın görevlendirdiği yöneticilerin sayısına göre farklılık gösterebilir; yani, halk egemenliğinin hükümet veya yönetim biçimi monarşik, aristokratik veya demokratik olabilir. Burada belirleyici olan, yönetimin egemen irade karşısında ikincil olmasıdır; yani yönetimi üstlenen 'görevliler' halkın genel iradesinin ifadesi olan yasaların sınırları içerisinde kaldıkları sürece halk egemenliği söz konusudur (bkz. Ağaoğulları, 2011:592-593).
} 
değil bir grubun iyiliğini gözetmelerine denk düşer ki Rousseau bunu, Ekonomi Politik'te kamusal ekonominin "despotik" uygulamasi olarak (Rousseau, 2005:16), Toplumsal Sözlesme'de ise egemenliğin yöneticiler tarafindan "gaspı" olarak adlandırır (Rousseau, 2004a:100-104). Yöneticilerin "tehlikeli bir ayrıcalık" yaratarak yasanın üzerine çıkma veya yasayla bağlı kalmama eğilimleri, yurttaşların tetikte olmalarını gerektiren daimi bir tehdit niteliğindedir.

Ne var ki bu açık uyarı, genel iradenin ifadesi olarak yasanın çoktan formüle edilmiş olduğu varsayımına dayanır. Oysa Rousseau'nun genel irade kavramsallaştırmasının barındırdığı zorluk, ortak iyinin tanımına nasıl ulaşılacağı sorusunda düğümlenir. İşte kamusal ekonominin ikinci kuralı bununla ilintilidir: Yönetim, genel iradenin yerine gelebilmesi için, özel-tikel iradeler ile genel irade arasındaki bağlantının koşullarını sağlamak durumundadır (Rousseau, 2005:22). Rousseau'nun siyasal kuramının siklıkla karşılaştığ eleştirilerden biri, siyasal toplumun kuruluş ve işleyişinde ahlaki koşulun fazlasıyla rol oynadığı tespitidir. Bir başka deyişle, Rousseau'nun modern cumhuriyetinde her şey "erdemli yurttaş"ın varlığına bağlıdır. Nitekim, kamusal ekonominin ikinci kuralı olarak özel iradelerin genel iradeye yönelmesini sağlamanın Rousseau'nun terminolojisindeki diğer adı, "erdemin hüküm sürmesini sağlamak"tır. Buna göre, yöneticilerin de öncelikli olarak 'görevlendirilmiş yurttaşlar' oldukları hesap edilirse, Rousseau'nun halk egemenliği kuramı siyasal bedenin bütününün iyiliğini daima kendi tikel çıkarlarının üzerinde görme kabiliyetine sahip yurttaşın varlığını gerektirir. Bu kabiliyet ise öğrenilen-öğretilen bir meziyettir ki burada Rousseau'nun yarattığı döngüsellik açıktır; erdemli yurttaşlar biraraya gelerek siyasal bedeni oluşturacak ve siyasal bedenin sürekliliği erdemli yurttaşların yetiştirilmesine bağlı olacaktır. Yurttaş yetiştirmek için cumhuriyetin başvuracağı araçlar olarak Rousseau'nun sıraladığı ve en çok dikkati çeken ise, yurt sevgisini aşlayacak bir kamusal eğitim, yurttaşlarda 'bütünlük' duygusunu pekiştirecek kamusal bayramlar, kutlamalar, ritüeller ve ana temas1 yine yurtseverlik olan "sivil din"dir (Rousseau, 2004a:154-168; Rousseau, 2005:24-28;31-35). Bu vurgular, Rousseau'nun ortaya koyduğu politik problemi salt ideolojik araçlara başvurarak çözmeyi denediği (Althusser, 1987:144-151) veya politik toplumu düşünebilmek için teolojik araçları sekülerleştirmeye duyulan ihtiyacı örneklediği (Critchley, 2013:72-77) biçimindeki yorumlara da zemin sunar. Ne var ki burada gözden kaçırılmaması gereken unsur "eşitsizliğin en büyük eleştirisini sunan" düşünür olarak Rousseau'nun (Riley, 2001:1), genel irade ile özel çıarlar arasındaki gerilimi çözme adına toplumsal eşitliği zorunlu bir koşul olarak gördüğüdür. Rousseau için eşitlik, özgürlüğün koşuludur; siyasal bedenin temel ilkesine denk düşer. Dolayısıyla eşitlik, genel iradenin oluşabilmesi için göründüğünden daha öncelikli bir ön koşuldur; nitekim kamusal ekonominin mali politikalarına yön veren ve servet eşitsizliklerine karşı önlem alma 
gereğini doğuran da bu temel ilke, yani eşitliğin gözetilmesi gereğidir (krş. Wood, 1983:309-314). Buradaki kasit, mutlak bir mülkiyet eşitliğini sağlamak değil, eşitsizliği sınırlandırmaktır. Rousseau'nun kuramının bütünü gözetildiğinde, bu sınır yurttaşların 'bağımsız' varoluşlarını garantilemek -yani ne muhtaçlık düzeyinde yoksul, ne de bir başkasının iradesini yönlendirebilecek kadar zengin olmamalarını sağlamak- şeklinde ifade edilebilir. Rousseau'nun ifadesiyle, "hiçbir yurttaşın bir başkasını satın alabilecek kadar zengin ve kendini satmak zorunda kalacak kadar yoksul olmaması" (Rousseau, 2004a:59), toplumun ortak çıkarını düşünüp bu yönde karar alabilmesi için herhangi bir güç odağına tabi değil, bağımsız olması gereken yurttaşın bir anlamda varoluş koşuludur. Yönetimin üçüncü görevi olarak "kamu maliyesi" başlığı altında çizilen çerçeve de bu temel ilkenin mali araç olarak vergilerde nasıl somutlanabileceğini anlatır.

Rousseau'ya göre, maliye yönetiminin temel ilkesi "gelirleri artırmak değil, ihtiyaçları sınırlamak" olmalıdır; gelirleri sürekli olarak arttırmaya odakl, kamu fonlanna dayalı bir ekonomi "bozulmanın ilk belirtisi"dir. Bu vurgu, Rousseau'nun yaşadığı dönemin dinamiği olan "para ekonomisinin" devlet maliyesini biçimlendiren etkisine yönelttiği temel eleştiridir; bununla birlikte, "finans eleştirisi" olarak görülüp günümüze uyarlanabileceği gibi, vergi politikasına ilişkin sıraladığı ilkeleri de tarihsel bağlamından soyutlayıp genelleştirmek mümkündür (Gürkan, 2016:164,172). Buna göre vergi, "geçimini ancak sağlayabilen" yurttaşlardan alınmamalı, diğer taraftan "geçim miktarını aşan servetin gerektiğinde tümü" vergilendirilebilmelidir. Toplumsallığın avantajlarından yararlanan "güçlü ve zengin" kimselerin, diğer bir ifadeyle makam ve mevki sahiplerinin toplumsal sistemden aldikları fayda da düşünülmeli, yani "adil ve oranlı vergi" servet "fazlalı̆g" ölçütüne göre işletilmelidir (Rousseau, 2005:46-49). Dolayısıyla Rousseau için vergileme, ekonomik ve toplumsal adalet sağlayacak mekanizmadır ve adil vergileme için kritik olan unsur, servetlerdeki fazlalıkların hesaplanmasıdır:

"Bütün bu hususlar özenle bir araya getirilirse şu sonuca varılır: Vergileri adaletli ve gerçekten oranlı biçimde dağıtmak için, bunların matrahları sadece mükelleflerin mal varlıklarılla basit orantılı olarak değil, toplumsal konumları arasındaki farklarla ve servetlerinin 'fazlalık' dereceleriyle doğru orantılı olarak saptanmalıdır. Bu (...) çok önemli ve güç bir operasyondur." (Rousseau, 2005:49).

Yönetimin vergi politikas1, "gerektiğinde kullanmaktan vazgeçilebilecek olan nesneleri" yani lüks tüketimi hedeflemelidir; Rousseau temel ihtiyaç maddelerinin vergilendirilmesini ise "mülkiyet hakkına, yani toplumun 
temeline saldırı" addetmektedir (Rousseau, 2005:55-56). ${ }^{13}$ Temel ihtiyaçların karşılanması dışındaki gelir-servet, Rousseau tarafindan kutsal veya dokunulmaz addedilmemekte, aksine yönetimin vergi gelirlerinin kaynağ olarak işaret edilmektedir. Bu kabullerde, modern kamu maliyesinde de geçerli olan "ödeme gücü ilkesi", "verginin nispi olması gerekliliğì", "asgari geçim indirimi ilkesi" gibi temel ilkeler ve ayrıca "eşit marjinal fedakarlık" olarak adlandırılan kuramsal ilkenin temel prensipleri açıça izlenebilmektedir:

Birinci olarak, nicel oranlar göz önüne alınmalıdır; buna göre, bütün diğer faktörler aynı kalmak koşuluyla, komşusundan on kat fazla malı mülkü olan bir kişi ondan on kat fazla vergi ödemelidir. İkinci olarak kullanıma ilişkin oranlar, yani gerekli olanla fazlalık [fuzili] olanın ayrımı gelir; [buna göre] ancak geçinecek kadar varlığa sahip olan birey hiç vergi ödememelidir. Bunun üstünde varlığ olana konacak vergi ise, ihtiyaç duyulduğunda, geçinmek için gerekli miktarı aşan artık servetin tümüne kadar çıabilir (Rousseau, 2005:46). ${ }^{14}$

Öte yandan, vergilerin eşitlik lehine kullanılmasına ilişkin sıralanan tüm bu ilkeler, ideal bir cumhuriyette kamusal ekonominin alacağı biçimi betimler. Oysa Rousseau, yönetimin daima genel iradenin hilafina bir eğilim göstereceği konusunda da, yöneticilerin kendi kişisel veya toplum içindeki bir grubun kısmi/tikel çıkarı lehine davranma eğilimi gösterecekleri konusunda da katidir. ${ }^{15}$ Kaçınılmaz addettiği bu eğilim karşısında, halkın

\footnotetext{
13 Özel mülkiyeti mevcut toplumların temelinde yatan ve eşitsizlikleri kurumsallaştırmaya neden olan bir "kandırmaca" olarak gören bir düşünür için (Rousseau, 2004b: 136-145) bu, oldukça şaşırtıı bir vurgudur. Fakat Rousseau'nun farklı metinlerde farklı bağlamlarda kalem oynattığı düşünüldügünde problem çözülür. İnsanlar Arasındaki Eşitsiə̧lĭgin Kökenine Dair Söylev'de eşitsizliğin kökenini mercek altına alan Rousseau, insanlar arasındaki doğal 'farklılıkların' toplumsal eşitsizliklere dönüşmesinin gerisinde, özel mülkiyet sahiplerinin bu ayrıcalıklarını kurumsallaştırma girişimlerinin yatı̆̆ı̆ı savunur; yani, burjuva/uygar toplumun verili hali, eşitsizlikleri koruma altına alan bir kandırmacaya, "yalancı sözleşme"ye dayanmaktadır. Dolayısıyla bu metinde özel mülkiyet, doğrudan siyasal sonuç yaratması gerekmeyen eşitsizliklerin, kurumsallaşarak toplumun temel ilkesine dönüşmesine yol açan bir tür 'gasp'tır. Ekonomi Politik'te "tüm yurttaş haklarının en kutsalı" addedilen mülkiyet ise (2005:36), Rousseau'nun bu temel düzey dışındaki serveti bir "fazlalık" olarak addetmesinden de anlaşılabileceği üzere, vergilendirme dışı tutulması gereken temel ihtiyaçlara eşitlenmektedir. Diğer bir ifadeyle, temel ihtiyaçları karşılamaya denk düşen gelir seviyesi tüm yurttaşlar için korunmalıdır; buna karşılık bu düzeyin ötesine geçen her tür gelir ve servet, gerektiğinde 'fazlalık' addedilip vergilendirme konusu yapılabilmelidir (bu konuda ayrıca bkz. Ağaoğullar1, 2005:65-67).

${ }^{14}$ Rousseau için bu vergi politikasının gerekçesi nettir: "[...] kişi, toplumsal konumu nedeniyle, aşağı tabakadan biri için fazlalık sayılacak varlığın kendisi için gerekli olduğunu ileri sürecektir, fakat bu bir yalandır; bir soylunun da bir sığırtmaç gibi iki bacağı vardır, karnı da tıpkı onun gibi bir tanedir" (Rousseau, 2005:46).

15 Aslında Rousseau'nun kurgusunda siyasal toplumun kuruluşu, siyasallaşmanın "getirisi"nin dahil olan herkes için "vazgeçilenlerden" daha fazla olduğu fikrine dayanır (Llyod, 1991:370).
} 
siyasal aktör olarak varlığını sürekli kılmasına hayati önem atfeder; tekil yurttaşların kamusal mevzulara daimi bir ilgi göstermesi ve düzenli halk toplantılarıyla biraraya gelmeleri, yöneticilerin ortak iyiliği bir 'bahane' olarak kullanmalarına karşı önerdiği yöntemlerdir (Rousseau, 2004a:106-110,119121; 2005: 30).

Bu bağlamda, hem Rousseau'nun siraladığ1 kamusal ekonomi ilkelerinin, hem de Piketty'nin günümüz eşitsizliklerine karş1 önerdiği yöntem olarak mali politikaların uygulanabilmesi, bu yönde gelişmiş bir siyasal iradenin varlığını dayanak almaktadır. Ne var ki neoliberalizm, tam da bu siyasal iradenin varlık koşullarını, yani siyasal bir özne olarak yurttaşı ve yurttaşın kendisini bir parçası hissedeceği 'halkı çözmek'le de eleştirilmektedir. Diğer bir ifadeyle neoliberalizm, Pierre Bourdieu'nun (2009:23) öne sürdügü gibi, "saf piyasa mantığını engelleyen kolektif yapıları yok etme programı" ise, sorun, eşitliği gözetecek siyasal iradenin doğuş koşullarında düğümlenmektedir.

\section{Neoliberalizm ve Siyasal Özne Sorunu}

Neoliberal dönüşümün etkin siyasal iktidarlar tarafindan üstlenildiği, bu anlamda 'siyaset sonrası' (post-politics) bir çağda yaşadığımızın iddia edilemeyeceği (Dean, 2009:23), bununla birlikte siyasal alanın kapsamı ve öznesiyle yeniden şekillendiği açıtır. Tüm olgusal çeşitliliğine rağmen neoliberalleşme deneyimleri "siyasal olanın yeniden biçimlendirilişi”" noktasında ortaklaşmakta, bu yolla, reform süreçlerinin toplumsal itirazlardan 'korunacak' biçimde işletilmesi hedeflenmektedir (Bedirhanoğlu ve Yalman, 2010:107-109). Dolayisiyla neoliberalizmi bir siyasal proje olarak değerlendirmek, devlet mekanizmasının yeniden yapılandırılmasını veya neoliberalizmin ideolojik-politik argümanlarını açıklamanın ötesinde (Bockman, 2012:312), bir bütün olarak siyasal alanın, neoliberal dönüşümün doğurduğu hoşnutsuzlukların yaratacağı çatışmalara 'kapalı', bu anlamda 'daha az demokratik' ve zor mekanizmalarına daha fazla yaslanan bir yeniden biçimlendirilişe tabi tutulduğunu (Bruff, 2014:113-115) tespit etmeyi mümkün kilmaktadır. 'Otoriteryan neoliberalizm' adlandırması altında giderek genişleyen ve farklı ülke örneklerinden beslenen literatür, derinleşen eşitsizlik ve güvencesizleşen yaşamlar üreten neoliberal reformların ancak otoriterleşen siyasal rejimler eliyle hayata geçirilebildiğine dikkati çekmekte;

Toplum içerisinde özgürlüğü mümkün kılmak ancak tüm üyelerin bu özgürlükten eșit pay almaları sayesinde mümkündür (Critchley, 2013:52-53); dolayısıyla ortaklı̆̆a kısmi çıkarlar lehine zarar vermek Rousseau'nun çerçevesinde gerçekte herkesi özgürlükten yoksun kılar ve "zincirlere" mahkum eder. Rousseau'nun kuramının temeli, ortaklığı ilgilendiren konularda yurttaşların kendi çıkarları ile siyasal toplumun adalet ilkeleri arasındaki uyuşmanın farkına varmalarında yatar; ne var ki yöneticilere ilişkin vurgusunda görüldüğü üzere bu uyuşmanın bozulması anlamında "yozlaşma" Rousseau'ya göre her topluma içkin bir eğilimdir. 
devletin yeniden yapılandırılmasını bu gözle konu edinmektedir. Bir yandan piyasadaki istihdam biçimlerinin disipline ediciliği, öte yandan devletin güvenlik siyaseti eliyle neoliberalizme sınıfsal bir itirazın siyasal alanda var edilebilmesinin önlenmesi, ${ }^{16}$ kuşkusuz, hem zor gücünü hem dönemin ruhuyla uyumlu yeni öznellikler yaratılmasını içeren çok boyutlu bir sürece yaslanmaktadir.

Bir "kültürel fenomen" olarak düşünüldüğünde neoliberalizm, piyasa işleyişinin hayatın tüm alanlarında belirleyici hale gelişini 'normal' ve yarattığ1 güvencesizliği 'kaçınılmaz' olarak gösterme başarısına sahiptir (Gilbert, 2013:12-15). Yeni türde bir öznellik üretme, bir yaşama ve davranma biçimi olarak düşünüldüğünde, neoliberal dönemin normu, "herkese genelleşmiş bir rekabet evreninde yaşamayı buyurur, halkların birbirileriyle iktisadi mücadeleye girmesini emreder, toplumsal ilişkileri piyasa modeline göre düzenler, birey dahil her şey dönüştürür; birey artık kendini bir şirket olarak tahayyül etmek durumundadır." (Dardo ve Laval, 2012:1). Aynı nedenle, Wendy Brown'a göre neoliberalizmin asıl tahribatınin "bomo politicus'u ortadan kaldırmak" olduğu tespit edilmelidir (Brown, 2018:31-35). Buna göre neoliberalizm, bireyi, kendisini hayatının her alanında bir "yatırım protföyü" gibi düşünüp davranışını buna göre şekillendiren bir bomo economicus olarak inşa etmektedir. Diğer bir ifadeyle, günümüz neoliberalizminde insan da bir sermayedir ve kendi kendisinin piyasa değerini arttırmak için uğraş vermek durumundadır. Ne var ki 'insan sermayesi olarak kendi portföy değerini arttırma'ya odaklı bu özne, kendi değerini arttırma rekabeti içerisinde piyasa rasyonalitesini içselleştirirken, gerçekte, piyasanın kolaylikla ikame edebileceği nesnelere dönüşerek değersizleşmektedir. Öte yandan, Brown, aynı bireylerin "kemer sıkma" politikaları aracilığılla 'sorumlulaştırıldıklarına', yani piyasanın krizlerinin sorumluluğunu üstlenmek zorunda bırakıldıklarına dikkati çeker. ${ }^{17} \mathrm{Bu}$

\footnotetext{
${ }^{16}$ Loic Wacquant, neoliberalizmi devletin yeniden yapılandırılması zemininde ele almakta, kısıtlayıcı istihdam politikaları ile cezalandırma mekanizmalarındaki genişlemeyi "neoliberal Leviathan" tabiriyle karşılamaktadır (Wacquant, 2010:198-200). Bu, neoliberalizmin derinleştirdiği eşitsizliklerden en çok etkilenen toplumsal kesimlerin kriminalize edilmeleri ve siyasal özne olarak varlık gösterebilme kapasitelerinin bu yolla sönümlendirilmesi anlamına gelmektedir. Neoliberalizm- otoriterleşme-güvenlikleştirme siyaseti arasında ilişkisellik kuran ve giderek zenginleşen literatürün genel bir değerlendirmesi için: bkz. Bedirhanoğlu, Dölek ve Hülagu, 2016.

17 Bireyin 'sorumlulaştırılması' tabirini anlayabilmek için, eleştirel literatürde 'insani yüzlü neoliberalizm' olarak anılan Üçüncü Yol'un teorik argümanlarını hatırlamak yararlı olacaktır. Üçüncü Yol'un teorisyeni Giddens'a göre bu birey (2003: 18), kamu hizmetlerinde "yurttaşmüşteri" ve piyasa ilişkilerinde "müşteri-yurttaş" olarak görülmelidir; her iki alanda da müşteri tatmini esas alınacağından bu formül sayesinde birey "gerçek egemen" haline de gelecektir. Giddens'ın burada yaptı̆̆ı, "yurttaş" tanımından sosyal hakları eksiltmek ve yurttaşı, haklarından ziyade, rekabet koşullarına uyum sağlama ve daha öncesinde sosyal devletin üstlendiği işlevleri üstlenme gibi çifte bir sorumluluk zemininde tanımlamaktır. Bu birey,
} 
modelde, insanın politik varoluşu da değersizleşmekte; tıpkı kamu mefhumunun ve kamusallığın varolabilmesi için hayati önemdeki hukuk ve eğitim alanları gibi, 18 politik alanın kendisi de neoliberal ekonomik rasyonaliteye göre yeniden şekillenmektedir. Başka türlü söylenirse, bireyi 'beşeri sermaye'ye dönüştüren neoliberalizm toplumsal ilişkileri de 'sosyal sermaye'ye dönüştürerek, doğrudan 'kamu' fikrini, kamusallığın varlık koşullarını ortadan kaldırmaktadır. Bu koşullarda piyasa aktörü olarak neoliberal dönemin bireyi, iddia edildiği gibi özgür değil, aksine "imkansız bir özgürlük"le malüldür; zira, hem hayatı üzerinde karar alma iktidarından yoksunlaştırılmış, hem de kamu mefhumunun parçası olmaktan çıkmış, yani "egemenlikten eksiltilmiş" durumdadir (Brown, 2018:45-46,126127,155,251-164). ${ }^{19}$ Brown, bu dönüşümün yalnızca bireyin değil, bir siyasal Özne olarak "halk"1n da çözülüşü anlamina geldiğine, dolayısıyla "halk egemenliği"ni yok ettiğine dikkati çekmektedir.

Brown'un bu vurgusu, katılımı oy verme pratiğiyle sınırlandıran günümüz 'demokrasileri' ile halk egemenliği arasındaki açının altını çizdiği gibi; 'yurttaş-tüketici'lerin, neoliberal programın 'seçenekleri' arasında tercih yapmalarının (Munck, 2007:116), "halkın yaşantısının temel maddi yönlerini" etkileyecek sonuçlar doğuramayacağını (MacEwan, 2007:285) da ima etmektedir. Tüm bunlarla birlikte, bu konuda bir kez daha Piketty'nin tespitlerine bakmak, bizzat yurttaşlar arasındaki eşitsizliğin, siyasal tercihlerde yansımasını izleyebileceğimiz başka bir etkisinin daha olduğunu göstermektedir.

Piketty'den bu bağlamda çıkarsanabilecek üç unsur vurgulanabilir: Egemenlerin maddi gücü artmış durumdadır; yeni orta sınıfin maddi çıkarı ile egemen sermayenin çıkarı örtüşür hale gelmiştir ve son olarak göreli

\footnotetext{
"rekabetçiliği" ve "dayanışmayı" kendi bünyesinde biraraya getirmeli; hem piyasa 'firsatlarını' değerlendirecek şekilde rekabetçi olmalı, hem de sosyal haklardan doğan boşluğu kendi dayanışma ağları ve 'kendi kendine yardım etme' (self-help) mekanizmaları ile doldurmalıdır (Morrison, 2004:171-175; Orton, 2004:519).

18 Brown'un neoliberal dönüşümün izini sürdüğü alanlar arasında eğitim, kamusallığın çözülmesi anlamında özellikle önemlidir. Modern cumhuriyet açısından kamusal eğitim, kamusal meselelerle ilgilenebilecek bilgi ve anlayışa sahip yurttaşlar yetiştirmenin temel aracı iken, neoliberal dönemin eğitimi bireylerin kendilerini birer insan sermayesine dönüştürmelerinin aracı olarak bir "şahsi yatırım"dan ibarettir (Brown, 2018:210-217). Diğer bir ifadeyle, halk egemenliği için hayati önemdeki kamusallık, var edilme ve yeniden üretilme araçlarının en önemlisinden, yani yurttaş olma pratiğinin öğrenildiği kamusal eğitimden yoksun bırakılmış durumdadır. Mac Ewan'a göre de (2007:287), eğitimin piyasalaşması yeni bir alanın metalaşmasının ötesinde anlam taşır; "eşitlik, uyum, ortak değerler, ortak dil" gibi toplumları var eden ortaklık mekanizmalarını mümkün kılan kamusal eğitim bu niteliğini yitirmektedir.

19 Benzer bir vurguyu Jayasuriya'da da (2005:2-7) görmek mümkündür; Jayasuriya, "neoliberalizmin toplumsallaşması" olarak adlandırdığı bu dönüşümün salt piyasa ilişkilerine göre tanımlanan "anti-siyasal bir yurttaşlık" ürettiğini öne sürmektedir.
} 
eşitsizlik tersine işleyerek bireyler için bir tatmin mekanizması olarak da işleyebilmektedir.

Piketty, artan oranlı gelir vergisinde en üst dilim oranının 1980 öncesine yükseltilebilmesinin uygulanabilir olduğunu ${ }^{20}$ ancak olası olmadığını, zira politik süreçlerin en üst \%1'lik kesimin kontrolü altında olduğunu öne sürer. Buna göre ekonomistler ve politikacılar, gelir hiyerarşisinin en üst kesimlerinde yer almakta ve kamu yararı ile kendi kişisel çıkarlarını birbirine karıştırmaktadırlar (Piketty 2014:556-557). Daha önemlisi, toplumsal yapıdaki dönüşümdür. Buna göre, günümüzde daha az zengin ama daha çok sayıda rantiyenin yaşadığı bir topluma, yani küçük rantiyeler toplumuna geçilmiştir (Piketty 2014:453). Dolayısıyla bu sınıfin rant temelli çıkarları neoliberalizmle uyum içinde varolabilmektedir. ${ }^{21}$

Son olarak, bir diğer maddi sorun, mutlak ve göreli eşitsizliğin anlam değiştirmesidir. Bertram'in (2015) yorumuyla söylenirse bu, Rousseau'nun amour propre (benlik sevgisi) olarak kavramsallaştırdı̆̆1 rekabetçi üstünlük arzusudur; neoliberalizmde en altta yer alan toplumsal kesimlerin dahi kendi amour propre'larını tatmin edebilecek birilerini bulmaları (yoksulların illegal göçmenlerle, yoksul beyazların yoksul siyahlarla ilişkisinde olduğu gibi) hiyerarşik toplumsal düzenin sürekliliğini sağlayan bir etkendir. Diğer bir ifadeyle, neoliberalizm, Rousseau'nun toplumsallı̆̆ın kökenine yerleştirdiği ve burjuva toplumda kültürün ana karakteri haline geldiğini söylediği rekabetçi üstünlük arzusunu besleyerek işlevselleştirmektedir. Göreli eşitsizlikten doğması ve eşitliğe doğru çözülmesi beklenir olan politik gerilim, tersinden işlemekte ve eşitsizliği koruyan bir tatmin mekanizmasına da dönüşmektedir. Bu ideolojik boyut da dahil olmak üzere, Piketty'den ç1karsanabilecek bu üç unsurun, eşitsizliğin norm haline gelişinde rol oynayan, ve dolayısıyla alternatif üretebilecek siyasal öznenin oluşumunu engelleyen neoliberal mekanizmaların bir diğer yüzünü oluşturduğunu söylemek mümkündür.

\footnotetext{
${ }^{20} \mathrm{Bu}$ vergi politikasının uygulanabilir olduğunu Piketty, şu tarihsel verilerle gösterir: 1944'te en yüksek gelir vergisi oranı ABD'de \%90 civarındadır; yine ABD'de 1932-1980 arasında neredeyse yarım yüzyll boyunca en yüksek federal gelir vergisi oranı \%81'dir ve 1940'larda İngiltere'de en yüksek vergi oran1 \%98'dir (Piketty 2014:549).

${ }^{21} \mathrm{Bu}$ yapısal dönüşüm temelde iki olguyla ilişkilidir; ilki, orta sınıf artık servet sahibidir ve ikincisi, mirasın etkisi artmıştır. Piketty, nüfusun \% 40'ına denk düşen orta sınıfın, servetin \% 30'una sahip olduğunu tespit eder ki bu "alelade bir dönüşüm değildir" (Piketty 2014:372, 276-278). Orta sınıf çağımıza özgü bir gerçekliktir ve bu sınıf için sermayenin getirisi ile miras belirleyici olgulardır. 1970-1980 yılları arasında doğanlar için mirasın servetteki payı, örneğin ABD’de \%60-70 oranına varacak kadar önem kazanmaktadır (Piketty 2014:461).
} 


\section{Sonuç}

Kapitalizmde sistemik olarak varolan ve günümüz neoliberalizminde gittikçe derinleşen ekonomik eşitsizlik olgusu, radikal müdahaleler gerektirmektedir. Bunun bir formunu, Piketty'nin tarihsel bulgulardan hareketle çıkarsadığ1 kamu maliyesi önerilerinde, her ne kadar kendisi önerilerini yumuşatarak formüle etse de, görebilmekteyiz. Ne var ki bu, Piketty'nin değindiği fakat kendisinin de çözümlemeye girişmediği bir noktayı, yani demokratik müdahale ve siyasal özne sorununu gündeme almayı gerektirmektedir. Bu çalışma, Piketty'nin servete ve gelire yönelik vergi müdahalesi gerekliliğine dair fikrinin Rousseau'nun eşitlik ilkesinde temellendirilebileceğini ve bu ilişkilendirmenin siyasal özne sorununa da belirli bir bağlamda yanıt üretebileceğini öne sürmektedir. Rousseau'dan hareketle işaret edilebilecek özne, kamusallık fikrine sahip çıkabilecek nitelikte bir siyasal öznedir; oysa neoliberalizm, yap1sal olarak bu siyasal öznenin maddi varoluş koşullarını ortadan kaldıran mekanizmalarla işlemektedir. Başka türlü söylenirse, neoliberalizm yurttaşın ve siyasal bedenin bütünü olarak halkın kendisini var edebileceği siyasal ve kamusal alanları çözmektedir. Tüm bu nedenlerden dolayı, ekonomik eşitsizliğin varolup olmadığ1 veya kamu maliyesi araçlarıyla önlenebilir olup olmadığı tartışmasını önceleyecek biçimde, neoliberalizmin doğurduğu esaslı sorunun siyasal özne sorunu olduğunu ileri sürmek mümkündür. 


\section{Kaynakça}

Ağaoğulları, M. A. (2005) Notlar, J. J. Rousseau, Ekonomi Politik içinde, (çev) İ. Berkan, İmge Kitabevi, Ankara.

Ağaoğulları, M. A. (2011) Jean-Jacques Rousseau: Halk Kendini Yaratıyor, (der.) M. A. Ağaoğulları, Sokrates'ten Jakobenlere Bati'da Siyasal Düsünceler içinde, İletişim Yayınları, İstanbul, 569-596.

Ağdemir, Z. (2018) Montesqueiu ve Rousseau'da Vergiler: Kısa Bir Giriş, Kirşebir Abi Evran Üniversitesi İktisadi ve İdari Bilimler Fakültesi Dergisi, 2 (1), 6-23.

Althusser, L. (1987) Rousseau: Toplum Sözleşmesi (Tutarsızllklar), L. Althusser, Politika ve Tarib içinde (çev) A. Şenel, Ö. Sezgin, V Yayınlar1, Ankara.

Badiou, A. (2007) Rousseau, A. Badiou, Being and Event içinde, Continuum, s. 344-354.

Bedirhanoğlu, P. ve Yalman G. L. (2010) State, Class and the Discourse: Reflections on the Neoliberal Transformation in Turkey, (der) A. Saad-Filho ve G. L. Yalman, Economic Transitions to Neoliberalism in Middle-Income Countries: Policy Dilemmas, Economic Crises, Forms of Resistance içinde, Routledge.

Bedirhanoğlu, P., Dölek, Ç., Hülagu, F. (2016) Eleştirel Güvenlik Çalışmalarının Marksist Eleştirisine Katkı: Devlet, Zor ve Sınıf Mücadelesi Bağlamında 'Güvenliği' Yeniden Düşünmek, Praksis, 40.

Bertram, C. (2015) Piketty, Rousseau and the Desire for Inequality, http://crookedtimber.org/2015/12/09/pikettyrousseau-and-the-desire-for-inequality/

Bockman, J. (2012) The Political Projects of Neoliberalism, Social Anthropology, 20 (3), 310-317.

Bourdieu, P. (2009) Sinırsız Sömürü Ütopyası, (der) G. Akalın ve U. S. Akalın, Neoliberal İktisadın Marksist Eleştirisi içinde, Kalkedon Yayınlar1, İstanbul.V

Brown, W. (2018) Halkın Cö̊ülïsü: Neoliberalizmin Sinsi Devrimi, (çev) B. E. Aksoy, Metis Yayınlar1, İstanbul.

Bruff, I. (2014) The Rise of Authoritarian Neoliberalism, Retbinking Marxism, 26 (1), 113-129.

Capaldi, N. ve Lloyd, G. (2016) Liberty and Equality in Political Economy, Edward Elgar Publishing. 
Clarke, S. (2007) Neoliberal Toplum Kuram1, (der) A. Saad-Filho ve D. Johnston, Neoliberaliẓm: Mubalif Bir Seçki içinde, (çev) Ş. Başli, T. Öncel, Yordam Kitap, İstanbul.

Clauson, M. (2014) Book Review on 'Capital in the Twenty-First Century', Journal of Markets \& Morality, 17 (2), 575-577.

Credit Suisse, Global Wealth Databook 2017, http://publications.creditsuisse.com/index.cfm/publikationen-shop/researchinstitute/global-wealth-databook-2017-en/

Critchley, S. (2013) Imansı̨larm Iman: Siyasal Teoloji Deneyleri, (çev) E. Ünal, Metis Yayınları, İstanbul.

Dardo, P. ve Laval, C. (2012) Giriş: Akılsallik olarak Neoliberalizm, P. Dardo, C. Laval, Dünyanın Yeni Akh: Neoliberal Toplum Üzerine bir Deneme içinde, (çev) I. Ergüden, Bilgi Üniversitesi Yayınları, İstanbul: 1-15.

Dean, J. (2008) Enjoying Neoliberalism, Cultural Politics, 4 (1), 47-72.

Dean, J. (2009) Politics without Politics, Parallax, 15 (3), 20-36.

Dean, M. (2014) Rethinking Neoliberalism, Journal of Sociology, 50 (2), 150 163.

Economist, Wealth Check: The Rich Get Richer and Millenials Miss Out, 16 Kasim 2017, https://www.economist.com/finance-andeconomics $/ 2017 / 11 / 16 /$ the-rich-get-richer-and-millennials-missout

Giddens, A. (2003) Neoprogressivism: A New Agenda for Social Democracy, (der) A. Giddens, The Progressive Manifesto içinde, Policy Network.

Gilbert, J. (2013) What Kind of Thing is 'Neoliberalism'?, New Formations, 80-81, 7-22.

Gürkan, C. (2016) Klasik Siyasal Düşüncede Maliye Teorisi: Bodin, Hobbes ve Rousseau, Yönetim ve Ekonomi Araștirmalan Dergisi, 14 (2), 148174.

Harvey, D. (2005) A Brief History of Neoliberalism, Oxford University Press, New York.

Jayasuriya, K. (2005) Economic Constitutionalism, Liberalism and the New Welfare Governance, Asia Research Centre, Working Paper no. 121 (wwwarc.murdoch.edu.au/wp/wp121.pdf)

Llyod, H. A. (1991) Sovereignty: Bodin, Hobbes, Rousseau, Revue Internationale de Philosophie, 45 (179), 353-379. 
MacEwan, A. (2007) Neoliberalizm ve Demokrasi, (der) A. Saad-Filho ve D. Johnston, Neoliberaliẓm: Mubalif Bir Seçki içinde, (çev) Ş. Başli, T. Öncel, Yordam Kitap, İstanbul.

Morrison, D. (2004) New Labour, Citizenship and the Discourse of the Third Way, (der) S. Hale, W. Leggett and L. Martell, The Third Way and Beyond içinde, Manchester University Press.

Orton, M. (2004) Irresponsible Citizens? New Labour, Citizenship and the Case of Non-Payment of Local Taxation, Critical Social Policy, 24 (4).

Piketty, T. (2014) Yirmi Birinci Yüzyılda Kapital, (çev) H. Koçak, İşbankası Kültür Yayınları, İstanbul.

Piketty, T. Capital in the 21th Century, http://piketty.pse.ens.fr/en/capital21c2

Riley, P. (2001) Introduction: Life and Works of Jean-Jacques Rousseau (1712-1778), (der) P. Riley, The Cambridge Companion to Rousseau, Cambridge University Press.

Rousseau, J. J. (2004a) The Social Contract, Penguin Books, Londra.

Rousseau J. J. (2004b) Insanlar Arasındaki Eşitsizliğin Kaynă̆g, (çev) Ü. Oksay, Say Yayınları, İstanbul.

Rousseau, J. J. (2005) Ekonomi Politik, (çev) İ. Berkan, İmge Kitabevi, Ankara.

Saad-Filho, A. ve Johnston, D. (2007) Giriş, (der) A. Saad-Filho ve D. Johnston, Neoliberaliẓm: Mubalif Bir Seçki içinde, (çev) Ş. Başli, T. Öncel, Yordam Kitap, İstanbul.

Thorsten, D. E. ve Lie, A. (2009) Neoliberalizm Nedir?, (der) G. Akalin ve U. S. Akalın, Neoliberal IKetisadın Marksist Eleștirisi içinde, Kalkedon Yayınları, İstanbul.

Wacquant, L. (2010) Crafting the Neoliberal State: Workfare, Prisonfare and Social Insecurity, Sociological Forum, 25 (2), 197-220.

Wood, E. M. (1983) The State and Popular Sovereignty in French Political Thought: A Geneology of Rousseau's 'General Will', History of Political Thought, 4 (2), 281-315. 